\title{
A COMPARATIVE STUDY OF THE DURATION OF LOCAL ANESTHESIA AND INTRA-OCULAR PRESSURE OF THE EYE IN PERIBULBAR BLOCK WITH AND WITHOUT HAYALURONIDASE
}

\author{
By
Tarek A. Seleem, Ahmed M. El-Garhy, Abdalla M.Gaafar*, and Mohamed M. Ghallab \\ Departments of Anesthesia and I.C.U, and Clinical Pathology, Faculty of Medicine, Al- \\ Azhar University, Cairo \\ Corresponding author: Mohamed M. Ghallab, Mobile: 01027408409 \\ E-mail: Mohamed_ghallab84@Hotmail.com
}

\begin{abstract}
Background: Regional anesthesia has gained wider popularity over general anesthesia, especially the combination of hayluronidase with local anesthesia in different ophthalmic surgeries aids to increase safety of procedure, less distortion of surgical site, decrease incidence of post-operative strabismus, and limits local anesthetic myotoxicty because of quicker spread.
\end{abstract}

Objective: Studying the effect of hayluronidase as an adjuvant to local anesthesia of the eye on the intraocular pressure and its effect on duration of local anesthesia.

Patients and Methods: A prospective randomized study was carried out on 40 patients divided into 2 equal groups; group A received local anesthesia without hayaloronidase, while group B received local anesthesia with hayaloronidase.

Results: The duration of sensory block in group A was $67.5 \mathrm{~min}$, and in group B was $90 \mathrm{~min}$. The IOP in group A was $27.5 \mathrm{~mm} \mathrm{Hg}$, and in group B was $21.5 \mathrm{~mm} \mathrm{Hg}$.

Conclusion: Combination of hayaloronidase with the local anesthesia mixture helped to decrease the intraocular pressure, thus made the operation easier with less complications, and helped to prolong the postoperative analgesia.

Key words: Local anesthesia, duration, intra-ocular pressure, peribulbar block hayaluronidase, postoperative analgesia.

\section{INTRODUCTION}

Regional anesthesia has gained wider popularity over general anesthesia, especially in different ophthalmic surgeries. The majority of patients undergoing ophthalmic surgeries are elderly, with multiple chronic diseases, which makes them at increased risk of morbidity and mortality under general anesthesia (Maha et al., 2014).

Different eye blocks have been practiced with great success. Peri-bulbar 
anesthesia is widely practiced now as a safe local block for cataract eye surgeries. However, the limited duration and large volume of the injected solution in these blocks were shown to be the main problem encountered intra operatively. Therefore, additional top-up doses are usually needed to continue the operation. Many researches tried to introduce solutions in order to prolong the duration and decrease the volume of the local anesthetics used. Several drugs were added as adjuvant to local anesthetics to help in spread of anesthetic mixture and accelerate onset as well as quality of the block (Maha et al., 2014).

Hyaluronidase use in ophthalmic surgery is beneficial, it has a depolymerizing action on hyaluronic acid, which is a component of connective tissue (Remy et al., 2008).

Hyaluronidase is an enzyme which degrades hyaluronan and has diverse clinical applications resulting from its ability to facilitate the dispersion and absorption of medications and fluids. It provides rapid penetration of anesthetic agents, particularly to locations difficult to access (Adams 2011).

In ophthalmology, hyaluronidase is used most often as an adjuvant to local anesthesia for retrobulbar, peribulbar and subtenon blocks (Amber et al., 2010).

The combination of hayluronidase with local anesthesia aid to less distortion of surgical site, decreased incidence of postoperative strabismus, and limits local anesthetic myotoxicty because of quicker spread. Also, it increases safety of procedure by increasing lid akinesia and allows using less anesthetic mixture volume (Becker and Reed 2012).
The aim of the study was to study the effect of hayluronidase as an adjuvant to local anesthesia of the eye on the intraocular pressure and post-operative analgesia.

\section{PATIENTS AND METHODS}

This prospective randomized study carried out on 40 ASA grade (I-II) adult patients for elective Phaco operation under local anesthesia, patients were divided for 2 equal groups (group A and group B).

Group A received local anesthesia without hyaluronidase, while group B received local anesthesia with hayluronidase to measure the duration of local anesthesia and the intra-ocular pressure.

After approval from ethical committee, an informed consent was obtained from all patients in this research. This study was done in Al-Hussein Hospital, Al-Azhar Faculty of Medicine.

The study included patients aged 5070 years, with no history of anti-coagulant therapy, no history of allergy to local anesthetics with axial length $<28 \mathrm{~mm}$.

\section{Exclusion criteria:}

Single eyed patients, bleeding disorders or patients on anticoagulant therapy, mental dysfunction, allergy to amide group of local anesthesia, sunken eye, glaucoma or any cause of pathological increased intra-ocular tension, trauma to the eye and traumatic cataract, axial length more than $28 \mathrm{~mm}$, recent myocardial infarction and uncontrolled hypertension.

\section{Preoperative assessment:}




\section{A COMPARATIVE STUDY OF THE DURATION OF LOCAL ANESTHESIA...}

All patients were subjected to medical history, physical examination and laboratory investigations (complete blood count, renal functions, liver functions, fasting blood sugar and prothrombin concentration).

\section{Anesthetic technique:}

According to the randomization method the patients were divided into 2 equal groups; Group (A) received $4 \mathrm{ml}$ lidocaine $2 \% \quad(80 \quad \mathrm{mg})$ and $4 \mathrm{ml}$ bupivacaine $0.5 \% \quad(20 \quad \mathrm{mg})$ without hayaluronidase (total volume $8 \mathrm{ml}$ ). A top up dose $(4 \mathrm{ml})$ of the same concentration may be used in case of inadequate block. Group (B) received $4 \mathrm{ml}$ lidocaine 2\% (80 $\mathrm{mg}), 4 \mathrm{ml}$ bupivacaine $0.5 \%$ (20 $\mathrm{mg})$, and 120 I.U hayaluronidase (total volume $8 \mathrm{ml})$. A top up dose $(4 \mathrm{ml})$ of the same concentration may be used in case of inadequate block. The hyaluronidase vial (consisting 1500 I.U.) was dissolved in lidocaine vial (consisting $50 \mathrm{ml}$ ) where each $\mathrm{ml}$ of lidocaine have 30 I.U of hyaluronidase.

Patients were fully monitored by electrocardiogram (ECG), pulse oximetry, and intermittent non-invasive blood pressure. Pre-operative hemodynamic data were recorded. In the supine position with eye in gaze position, a $10 \mathrm{ml}$ syringe with a $25 \mathrm{G}$ needle was used for peribulbar injection.

The block was divided into 2 injections; the infero-temporal injection which has been given at the junction of the outer one third and inner two thirds of the lower orbital rim, and the medial injection which was given with a sharp bevel facing the globe. The needle was inserted between the medial caruncle and the medial canthus, $20 \mathrm{~mm}$ deep in a perpendicular direction to the frontal plane.

In both groups, motor and sensory block were measured. The onset of motor block was measured by globe akinesia. Globe akinesia assessed by scoring the ocular movements at 2-minute interval in each direction of gaze (superior, inferior, medial and lateral), using a 3 point scale or ocular movement score (0-complete akinesia, 1-limited movement, 2- normal movement). The onset of sensory block were assessed by disappearance of ocular sensation, using a cotton wick at every 30 seconds till the onset of anesthesia.

If the block was inadequate after 10 minutes, a $4 \mathrm{ml}$ supplementation of local anesthetics were given by the same technique after adequate sensory and motor block (loss of sensation to touch by a small cotton wool) and complete akinesia, the surgeon is informed to start the surgery.

Postoperative pain was recorded by using a 5-points verbal rating score, i.e. 0 no pain, 1-mild pain, 2-moderate pain, 3severe pain, 4-unbearable pain. It was assessed immediately after surgery then every $15 \mathrm{~min}$ interval to measure the duration of sensory block of local anesthesia from the start of block.

The onset of motor block was measured by disappearance of ocular movement in four directions (superior, inferior, medial and lateral) after giving the local anesthesia. The duration of motor block were not measured postoperative because the eye is covered with eye patch and it is difficult to remove it to assess the motor block for the safety of operation. The duration of the surgery was recorded. The intra ocular pressure was 
measured before the block, 1 min after the block, and 5 min after the block using tonometry (Kouchaki et al., 2017).

\section{Statistical Analysis:}

Data entry, processing and statistical analysis was carried out using MedCalc ver. 18.2.1 (MedCalc, Ostend, Belgium). Tests of significance (Mann-Whitney's, Chi square tests, multiple regression analysis, Spearman's correlation, and ROC Curve analysis) were used. Data were presented and suitable analysis was done according to the type of data (parametric and non-parametric) obtained for each variable. P-values less than 0.05 (5\%) was considered to be statistically significant.

\section{RESULTS}

Comparative study between the 2 groups as regard axial length, IOP. HTN, $\mathrm{DM}$, obesity, and previous eye surgeries revealed non-significant difference as regards all basic clinical data $(\mathrm{p}>0.05-$ Table 1).

Table (1): Comparison between the 2 groups as regards basic clinical data using Mann-Whitney's U and Chi square tests

\begin{tabular}{|c|c|c|c|c|}
\hline \multirow[t]{2}{*}{ Variables } & \multirow[t]{2}{*}{ Groups } & $A \operatorname{group}(20)$ & $B$ group $(20)$ & $\begin{array}{l}\text { Mann- } \\
\text { Whitney's } \\
\text { U test }\end{array}$ \\
\hline & & Median (IQR) & Median (IQR) & $\mathrm{P}$ value \\
\hline \multicolumn{2}{|l|}{ Axial length $(\mathrm{mm})$} & $24.5(22-26)$ & $26(23-27)$ & $=0.383$ \\
\hline \multicolumn{2}{|c|}{ IOP baseline (before block) $(\mathrm{mmHg})$} & $20(18-25)$ & $23(20-25)$ & $=0.062$ \\
\hline \multirow{2}{*}{\multicolumn{2}{|c|}{ Variables }} & \multirow[t]{2}{*}{$A \operatorname{group}(20)$} & \multirow[t]{2}{*}{$B$ group $(20)$} & $\begin{array}{l}\text { Chi } \\
\text { square } \\
\text { test }\end{array}$ \\
\hline & & & & $\mathrm{P}$ value \\
\hline HTN & $+\mathrm{ve}$ & $8(40 \%)$ & $12(60 \%)$ & $>0.05$ \\
\hline DM & +ve & $14(70 \%)$ & $11(55 \%)$ & $>0.05$ \\
\hline Obesity & +ve & $9(45 \%)$ & $5(25 \%)$ & $>0.05$ \\
\hline Previous eye surgeries & $+\mathrm{ve}$ & $8(4 \%)$ & $8(40 \%)$ & $>0.05$ \\
\hline
\end{tabular}

*HTN: hypertension, *D.M.: Diabetes mellitus, * IOP: intra ocular pressure.

Comparative study between the 2 groups revealed non-significant difference as regards baseline HR, MAP and oxygen saturation, significant decrease in 1 and 5min post-injection IOPs, in B group, compared to A group. Comparative study between the 2 groups revealed significant increase in duration of sensory block, in B group, compared to A group. The duration of motor block were difficult to be measured because the eye was covered with eye patch post-operative (Table 2). 
A COMPARATIVE STUDY OF THE DURATION OF LOCAL ANESTHESIA...

Table (2): Comparison between the 2 groups as regards baseline hemodynamic and intra operative data using Mann-Whitney's $U$ test

\begin{tabular}{|c|c|c|c|}
\hline \multirow[t]{2}{*}{ Variables } & A group $(20)$ & B group $(20)$ & $\begin{array}{l}\text { Mann- } \\
\text { Whitney's } \\
\text { U test }\end{array}$ \\
\hline & Median (IQR) & Median (IQR) & $\mathrm{P}$ value \\
\hline HR baseline (beat/min) & $76(69-80)$ & $79(71-83)$ & $\begin{array}{l}=0.342> \\
0.05\end{array}$ \\
\hline MAP baseline $(\mathrm{mmHg})$ & $82(80-90)$ & $78(74-85)$ & $\begin{array}{l}=0.098> \\
0.05\end{array}$ \\
\hline O2 saturation baseline $(\%)$ & $98(97-98)$ & $98(97-98)$ & $\begin{array}{l}=0.577> \\
0.05\end{array}$ \\
\hline IOP 1 min. (after block) $(\mathrm{mmHg})$ & $29(24.5-33)$ & $23(20-27)$ & $=0.0008$ \\
\hline IOP 5 min. (after block) (mmHg) & $27.5(23.5-31.5)$ & $21.5(19.5-25.5)$ & $=0.0003$ \\
\hline Duration of sensory block (min) & $67.5(60-90)$ & $90(75-97.5)$ & $=0.0014$ \\
\hline
\end{tabular}
MAP: mean arterial pressure. HR: heart rate.

Correlation studies between postoperative outcomes; and its relative independent predictors (basic clinical, preoperative variables) were conducted with multiple regression analysis and Spearman's correlation coefficient (figure $1)$.

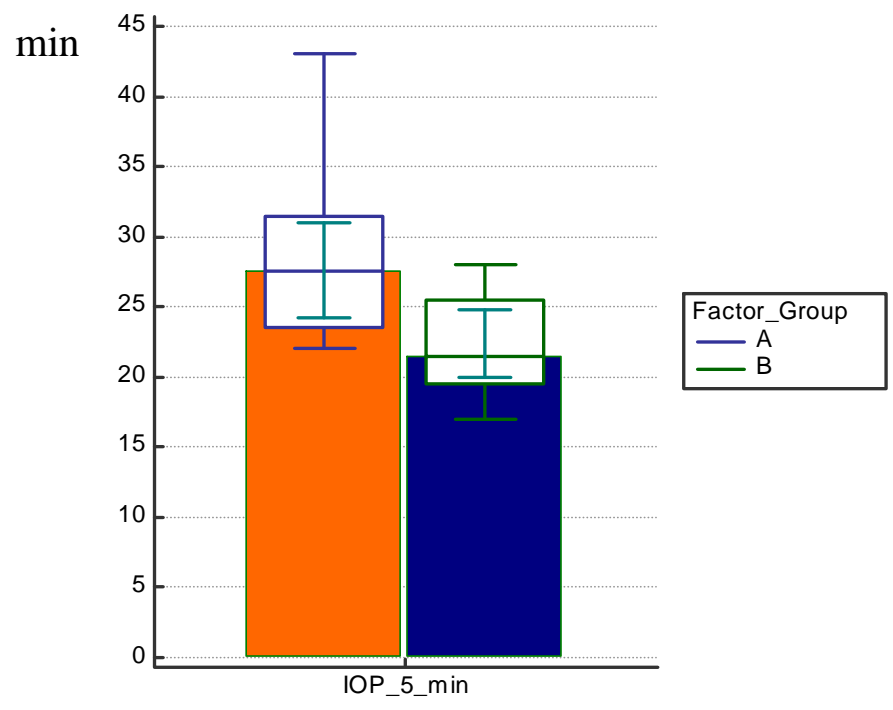

Figure (1): Correlation between5-min post-injection IOP and hyaluronidase usage group

Multiple regression analysis showed that, after applying (Forward method) and entering some predictor variables, the increase in hyaluronidase usage had an independent effect on increasing duration of local anaesthesia with significant statistical difference (Table 3). 
Table (3): Multiple regression model for the Factors affecting duration of local anesthesia using Forward method

\begin{tabular}{|l|l|l|l|}
\hline Predictor Factor & B & SE & P \\
\hline (Constant) & 52.0263 & & \\
\hline Group = B "hyaluronidase usage" & 18.2368 & 4.9905 & $0.0008^{* *}$ \\
\hline
\end{tabular}

--- excluded from the model if ( $\mathrm{p}$ value > 0.1) --- $\beta$ : Regression coefficient, SE: Standard error.

By using ROC-curve analysis, with good accuracy, sensitivity $=100 \%$ hyaluronidase method predicted and specificity $=50 \%$ (figure 2 ).

significant post-operative IOP reduction,

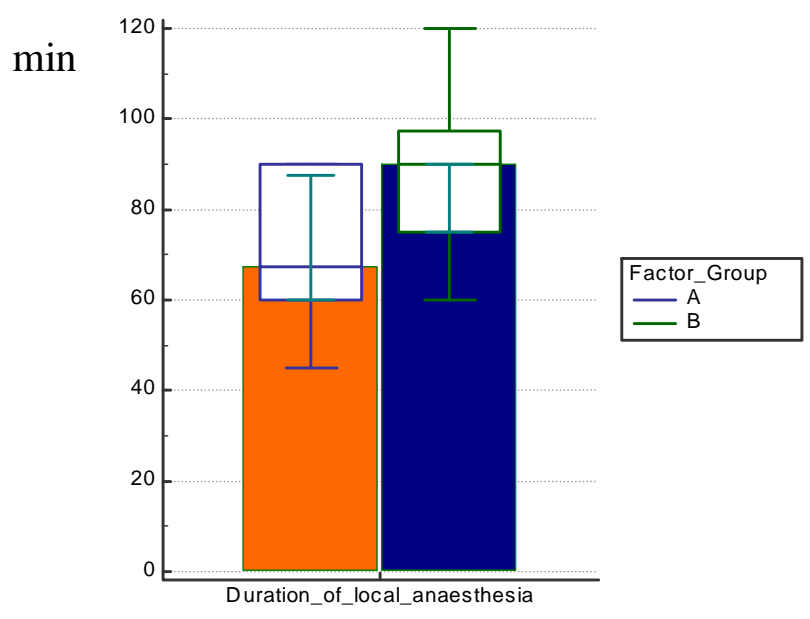

Figure (2): Correlation between duration of local anaesthesia and hyaluronidase usage group.

By using ROC-curve analysis, duration, with good accuracy, sensitivity= hyaluronidase method predicted $100 \%$ and specificity $=50 \%$ (figure 3 ).

significant increase in local anesthesia

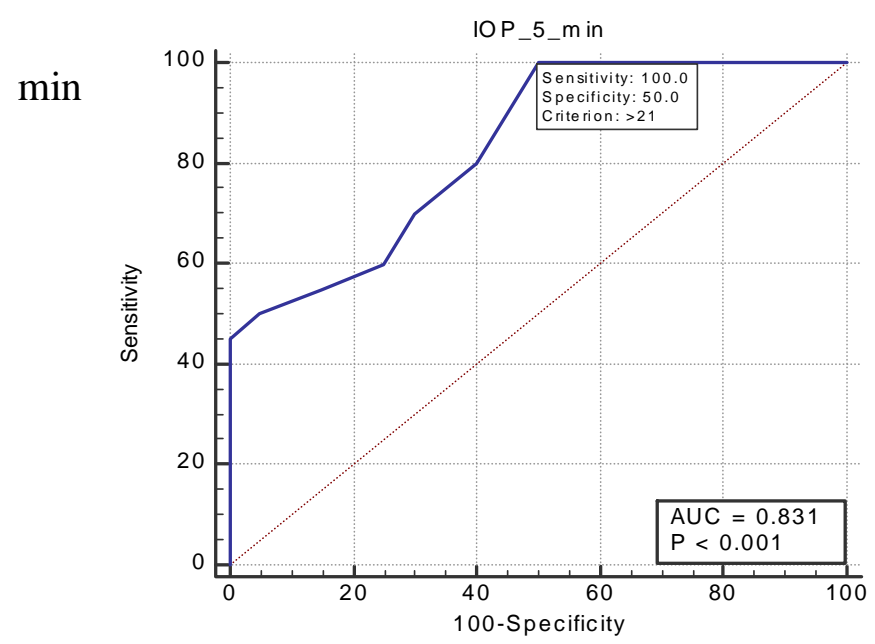

Figure (3): ROC curve of post-injection IOP reduction 


\section{A COMPARATIVE STUDY OF THE DURATION OF LOCAL ANESTHESIA...}

By using ROC-curve analysis, duration, with fair accuracy, sensitivity= hyaluronidase method predicted $50 \%$ and specificity $=95 \%$ (Figure 4).

significant increase of local anaesthesia

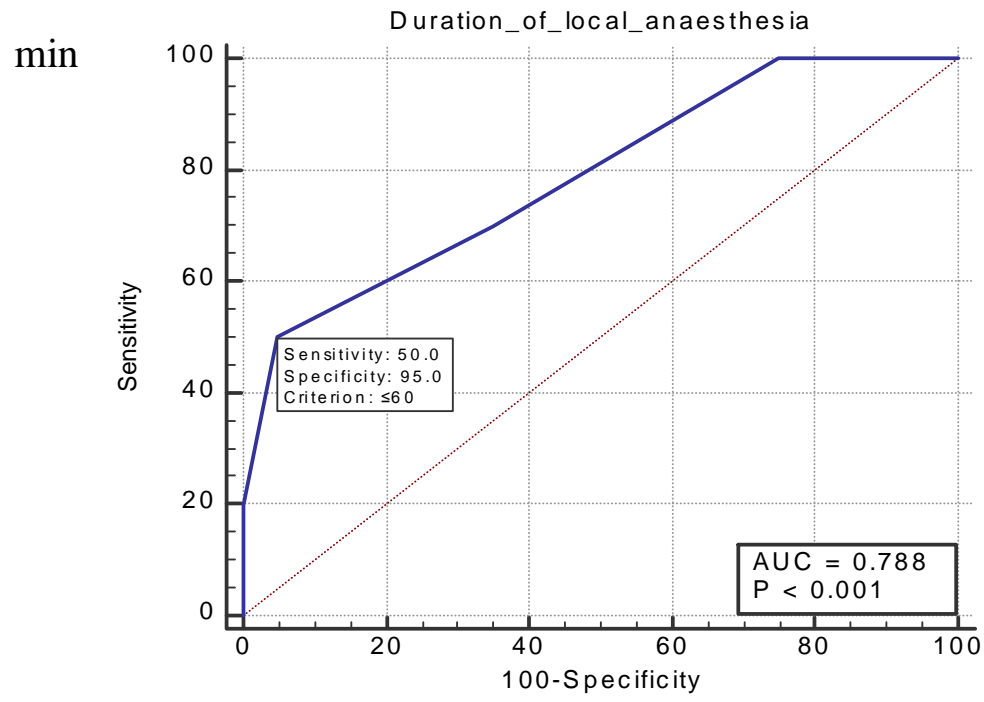

Figure (4): ROC curve of increase of local anaesthesia duration

\section{DISCUSSION}

This was a prospective comparative study conducted on fourty ASA grade (III) adult patients for elective phaco operation under local anesthesia to evaluate the effect of hyaluronidase as an adjuvant to local anesthesia of the eye on the intra-ocular pressure and the duration of local anesthesia.

Patients were divided into 2 equal groups, group A and group. The study was held in the ophthalmic operating theatre at Al-Hussein Hospital, Al-Azhar Faculty of Medicine.

Group A received local anesthesia without hyaluronidase, while group B received local anesthesia containing hyaluronidase to compare between the two groups.

In group A the average IOP before block ranged between $18-25 \mathrm{~mm} \mathrm{Hg}$ with average $20 \mathrm{~mm} \mathrm{Hg}$. After 1 min block it varied between $24.5-33 \mathrm{mmHg}$ with an average of $29 \mathrm{~mm} \mathrm{Hg}$, after 5 min block it varied between $23.5-31.5 \mathrm{~mm} \mathrm{Hg}$ with an average of $27.5 \mathrm{~mm} \mathrm{Hg}$.

In group $\mathrm{B}$, the average IOP before block ranges between $20-25 \mathrm{~mm} \mathrm{Hg}$ with average $23 \mathrm{~mm} \mathrm{Hg}$, after 1 min block it varies between $20-27 \mathrm{mmHg}$ with average $23 \mathrm{~mm} \mathrm{Hg}$, after 5 min block it varies between $(19.5-25.5 \mathrm{~mm} \mathrm{Hg})$ with average $21.5 \mathrm{~mm} \mathrm{Hg}$.

Regarding the duration of local anesthesia, in group A it ranges from 60$90 \mathrm{~min}$ with average $67.5 \mathrm{~min}$, in group B it ranges from $75-97.5$ min with average 90 min, which indicates that hyaluronidase affects slightly duration of local anesthesia.

Comparative study between the 2 groups revealed highly significant decrease in 1 and 5-min post injection IOPs, in B group; compared to A group; 
with highly significant statistical difference

The study showed that hyaluronidase significantly affects the intra-ocular pressure, patients of group B shows significant decrease in IOP $1 \mathrm{~min}$ and 5 min after receiving local anesthesia.

Ngangom et al. (2017) made a comparison of lignocaine $2 \%$ with adrenaline (group A) and a mixture of bupivacaine $0.5 \%$ plus lignocaine $2 \%$ with hyaluronidase (group B) for peribulbar block to compare the efficacy of both solutions by analyzing akinesia and analgesia for both groups. There were significant better results for akinesia obtained for the combination of lignocaine $2 \%$ plus bupivacaine with hyaluronidase at $10 \mathrm{~min}$ after injection and also at the end of the surgery. However, with regard to analgesia, both $2 \%$ lignocaine and $2 \%$ lignocaine with $0.5 \%$ bupivacaine had a similar effect. Furthermore, the patients in Group B showed a significantly reduced need for the first supplemental injection and no need for a second supplemental injection. The incidence of complications was very low in this study. No serious local or systemic complication was encountered.

Schelenburg et al. (2007) made a comparison between sub-tenon's block with and without hyaluronidase to see the effect of hyaluronidase in reducing volume of sub-tenon's anesthesia. Patients divided into 2 groups, group A received lidocaine $2 \%$ without hayluronidase while group B received lidocaine $2 \%$ with hyaluronidase 15 IU/ML. In group B, the median local anesthesia volume was 2.6 $\mathrm{ml}$, while in group A the median local anesthesia volume was $6.4 \mathrm{ml}$. This indicates that hayluronise permits a significant 2.4 fold reduction in median local anesthesia volume required for subtenon's block.

Ruschen et al. (2018) made test to see effectiveness of adding hyaluronidase to local anaesthetic eye block solutions to reduce pain and increase participant and surgical satisfaction during eye surgery in adults. 500 adult patients undergoing eye surgery under local anesthesia, pain, patient satisfaction, surgical satisfaction was recorded. The results shows that there is no significant difference between patients received local anesthesia with hayluronidase and patients received local anesthesia without hayluronise at level of pain, Patient and surgical satisfaction is higher in the group receiving hyaluronidase. So the conclusion is, hayluronidase has no effect in reducing pain in local anesthetic block but it increases patient and surgical satisfaction to local block.

Nagarajan et al. (2018) made a study to determine the necessity of hyaluronidase as an anesthetic adjuvant for peribulbar anesthesia during cataract surgery and to assess differences in anesthetic outcomes in the absence of hyaluronidase. The study made on 200 patients reported for cataract surgery. Patients divided into 2 groups, droup A without hyaluronidase, group B with hyaluronidase. Surgeons scored for akinesia, patients scored for analgesia. There was no statistically significant difference between the two groups in akinesia and analgesia. Onset of akinesia and analgesia was earlier in group B. 


\section{A COMPARATIVE STUDY OF THE DURATION OF LOCAL ANESTHESIA...}

\section{CONCLUSION}

The use of hayaloronidase in the local anesthesia mixture helped to decrease the intraocular pressure, which made the operation easier with less complications, and helped to prolong time of postoperative analgesia.

\section{REFERENCES}

1. Adams L. (2011): Adjuvants to local anaesthesia in ophthalmic surgery. $\mathrm{Br} \mathrm{J}$ Ophthalmol. 95(10):1345-9.

2. Becker D E and Reed K L. (2012): Local anesthetics: review of pharmacological considerations. Anesth Prog. 59(2): 90-101.

3. Devi N S and Singh $K$ N. (2019): Comparison of lignocaine $2 \%$ with adrenaline and a mixture of bupivacaine $0.5 \%$ plus lignocaine $2 \%$ with hyaluronidase for peribulbar block analgesia. Indian J Anaesth. 32: 190-4.

4. Dunn A L, Heavner J F, Racz G and Day M. (2010): Hyaluronidase: A review of approved formulations, contraindications, and off label use in chronic pain management. 127-31.

5. Kouchaki B, Hashemi H, Yekta $A$ and Khabazkhoob M. (2017): Comparison of current tonometry techniques in measurement of intraocular pressure. J Curr Ophthalmol. 29(2):92-7.
6. Nagarajan, Swathi K, Srikanth $\mathrm{S}$ and Venipriya R, (2018): Does the addition of hyaluronidase improve the quality of peribulbar anesthesia in cataract surgery? Saudi Journal of Ophthalmology. 32: 204-10.

7. Remy M, Pinter F, Nentwich M M, Kampik $A$ and Sch?nfeld C-L.(2008): Efficacy and safety of hyaluronidase $75 \mathrm{IU}$ as an adjuvant to mepivacaine for retrobulbar anesthesia in cataract surgery. J Cataract Refract Surg. 34(11):1966-9.

8. Rüschen $\mathrm{H}$, Aravinth $\mathrm{K}$, Bunce $\mathrm{C}$ and Bokre D march. (2018): Addition of hyaluronidase to local anaesthetic eye blocks to reduce pain during eye surgery in adults. . Br J Ophthalmol. 89(3): 291-293.

9. Schulenburg H E, Sri-Chandana C, Lyons G, Columb M O and McLure BJA. (2007): Hyaluronidase reduces local anaesthetic volumes for sub-Tenon's anaesthesia. British Journal of Anaesthesia, 99: 717-20.

10. Youssef $M I$, Girgis $K$ and Soaida $S M$. (2014): Clonidine versus fentanyl as adjuvants to bupivacaine in peribulbar anesthesia. Egyptian Journal of Anaesthesia. 30(3) 26772. 
در اسة مقارنه على مدة التخدير الموضعي و الضغط داخل

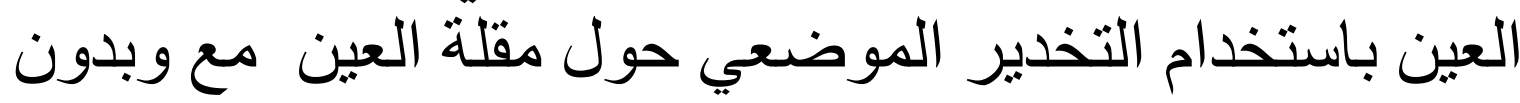
عقار الهيالورونيديز

طارق عبد السلام سليم ـ أحمد محمود الجارحي ـ عبد الله مصطفي جعفر - محد محمد ممدوح غلاب

قسم التخدير والغناية المركزة و قسم الباثولوجيا الاكلينيكيه ـ كلية الطب ـ جامعة الأزهر ـ القاهرة

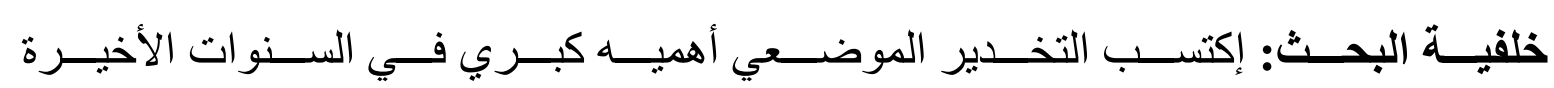

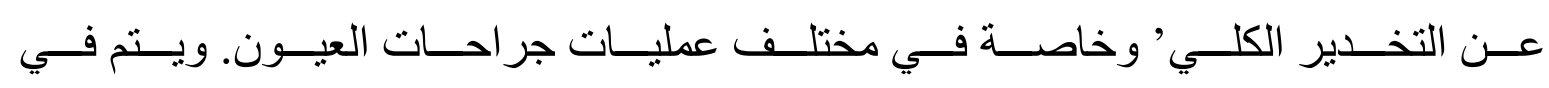

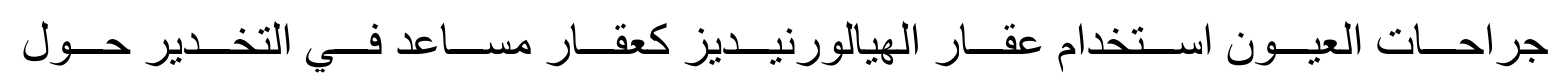

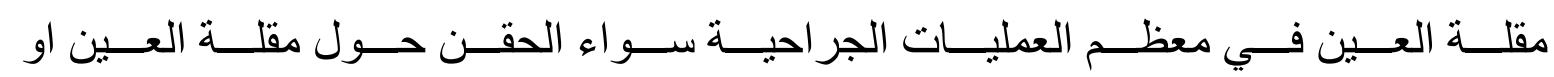
ور اء مقلة العين.

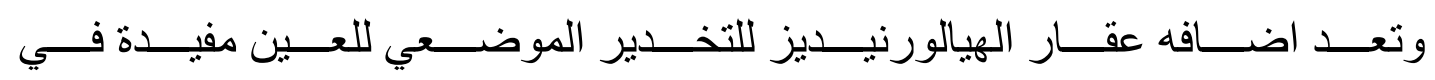

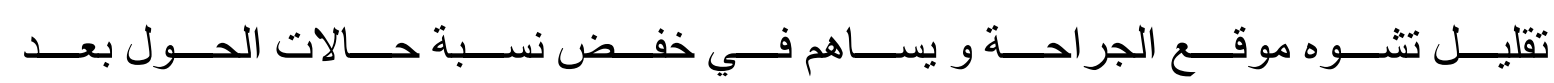

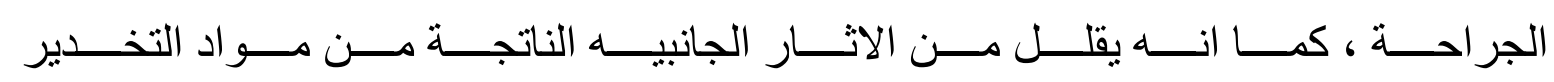
الموضعي نتيجة تقليل كميتها.

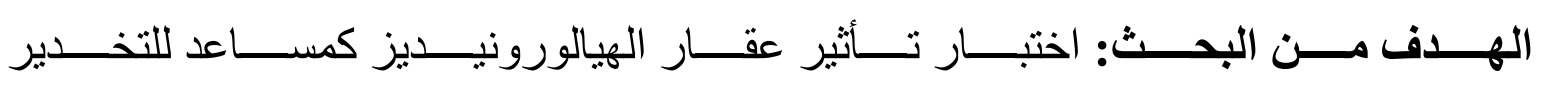
الموضعي للعين علي الضغط داخل العين ومدة التخدير الموضعي للعين.

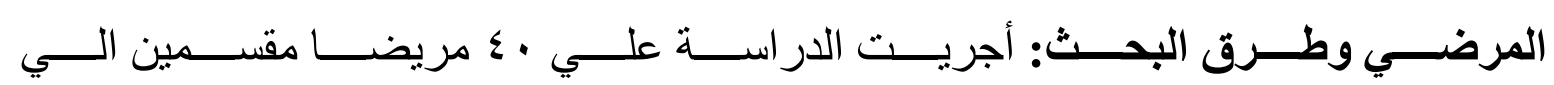

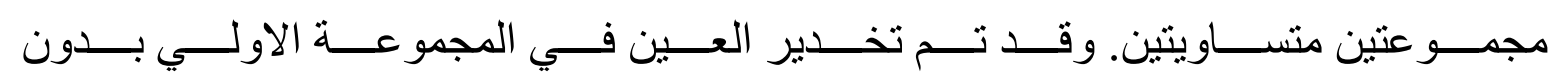

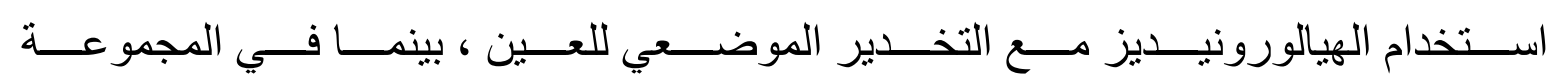
الثانية تم تخدير العين باستخدام الهيالورونيديز مع التخدير الموضعي للعين.

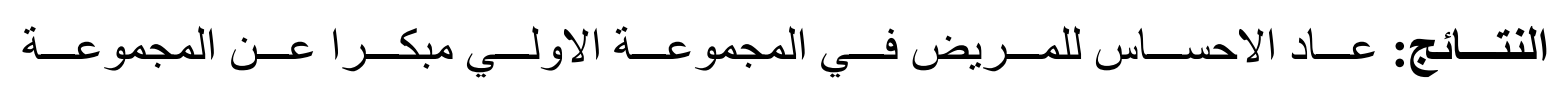

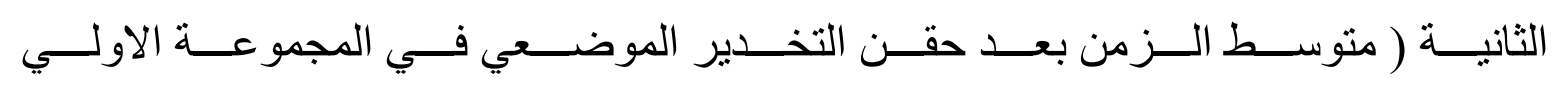




\section{A COMPARATIVE STUDY OF THE DURATION OF LOCAL ANESTHESIA....}

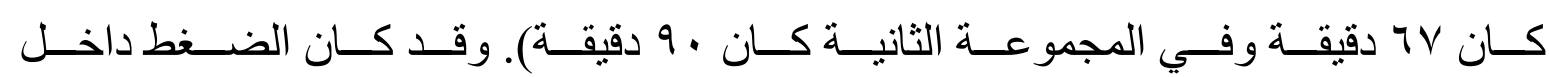

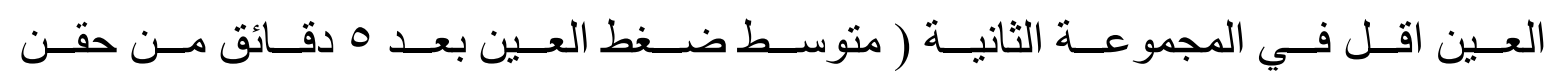
التخدير الموضعي في المجمو عة الاولي.

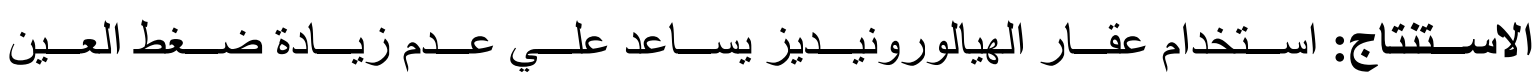

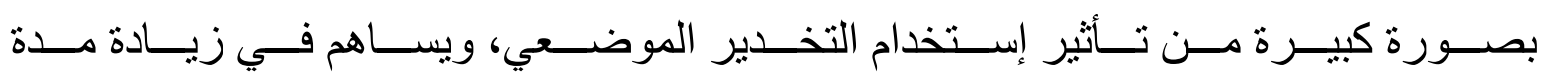

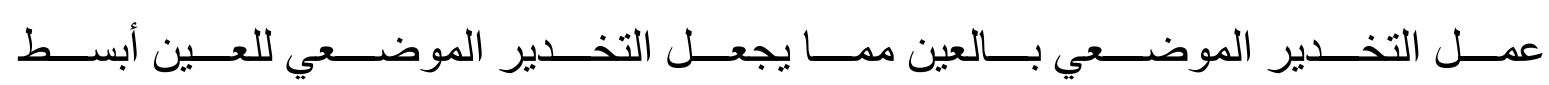
و أسهل. 